\title{
The Balanced Scorecard as a Measure for Performance of Banks in Lebanon: A Review of Literature
}

\author{
ANIS EL KHATIB \\ Head of the Anti-Money Laundering Compliance Department, Middle East Airlines, Lebanon \\ Email: elkhatiba@mea.com.lb \\ Tel: +9613650525
}

PIERRE AL-KHOURY

Vice President for Development, Lebanese German University, Lebanon

E-mail: p.khoury@1gu.edu.lb

Tel: +9613230848

\begin{abstract}
The Lebanese Banking Sector performs a vital role in the economic development of the country. Currently, Lebanese banks are engaged in a wide range of activities, offering variety of financial products and services to resident and non-resident customers. In addition to the distinguished products offered to the business sector, Lebanese banks have also entered the retail market by offering a wide range of products to the household sector. Managing such a portfolio of products and services needs high efforts and comprehensive data analysis to get high customer satisfaction and loyalty. To face competition, especially from MENA banks, Lebanese banks are in a continual need to design new products, upgrade technology and infrastructure, improve employees' skills and know-how, and improve relations with customers The more the sound the banking system, the more will be the healthy economy. Lebanese banks are still measuring and evaluating the performance of their business using only financial measures. Till our days, the idea of introducing non-financial measures and/or performance management systems to measure the performance of banks is still away from the strategies of Lebanese bankers. Moreover, the review of literature showed no evidence related to the evaluation of Lebanese banks using both financial and nonfinancial measures, mainly performance management system as the Balanced Scorecard. Accordingly, it is highly recommended encouraging banks to adopt the Balanced Scorecard as a complementary tool to measure performance, knowing that Lebanese banks are anticipated to face a new era of challenges due to the extraction of gas resources, the expected reconstruction process of Syria, and the development of the banking sectors in the Arab Gulf Area.
\end{abstract}

Keywords: Banking Sector, Balanced Scorecard, Financial and Non-Financial Measures, Customers' Loyalty, Performance Measurement Systems, Evaluation of Banks.

\section{Introduction}

The Lebanese Banking Sector has a reputable and credible history in the Middle East. Beirut, the capital of Lebanon, has historically developed as one of the most attractive international financial centers in the region. The liberal democratic system, coupled with a solid banking infrastructure, has made the country a haven deposit box, especially for Petro-dollar funds from the Gulf countries. Open connections, and free trade, with both Arab and European nations, are only two of the features that Lebanon has exercised and practiced along its modern history. Consequently, this has made Lebanon develop as a country, with a free market economy, and with minimum state control. All of which have reinforced and further strengthened 
the monetary system of the country, which has significantly spilt over, creating a solid foundation for an efficient banking system.

Despite the tragic events, in both its economic and political dimensions, that Lebanon has sadly had to go through over the past hundred years, one of the strongest survivors and the most resistant to such turmoil has been the "banking system of Lebanon". Over the past century, the Lebanese Banking Sector has been the driving engine of the nation's economy. The Lebanese banking sector has a distinguished history, in the Middle East, and throughout the world. It has long been highly-regarded for its openness, stability, and sophistication. Moreover, throughout Lebanon's history, it has played an important role in the private sector, and in sustaining the public sector.

During the coming decade, it is expected that the Lebanese banks are going to face a new challenge. Studies have assured that Lebanese territorial waters contain considerable reserves of gas. The Lebanese authorities have already established an administrative body to supervise the depletion of gas resources. The Lebanese Banking Sector should play a crucial role in financing the processes associated with gas extraction. Such a role is expected to face severe competition from regional and international financial institutions. On the other side, the high capitalization and international exposure and experience of the Lebanese banks put them now in a perfect position to move to a new era of development by benefiting from the rehabilitation and reconstruction process that is expected to take place in Syria. The Lebanese banks should play the role that Syrian banks are unable to do with their traditional structure and limited international exposure. Consequently, and to be prepared for the gas extraction and the reconstruction of Syria, Lebanese banks may need to be engaged in merger activities, or alliances, to meet the forthcoming competition. Moreover, the Lebanese authorities need to issue more rules and regulations to absorb the anticipated openings of new foreign banks.

Lebanese banks are still measuring and evaluating the performance of their business using only financial measures. Till our days, the idea of introducing non-financial measures and/or performance management systems to measure the performance of banks is still away from the strategies of Lebanese bankers. This is mainly noticed in the various types of reports issued by banks. Moreover, the review of literature showed no evidence related to the evaluation of Lebanese banks using both financial and non-financial measures, mainly performance management system such as the Balanced Scorecard (BSC) it is highly recommended that the Central Bank of Lebanon- Banque Du Liban (BDL) and the Association of Banks In Lebanon (ABL) start encouraging banks to adopt performance management systems that reflect both the financial and the no-financial activities of banks. It is highly believed that this is crucial since the Lebanese Banking Sector is anticipated to face new era of challenges due to the extraction of gas resources, the expected reconstruction process of Syria, and the development of the banking sectors in the Arab Gulf Area. The adoption of a reliable and comprehensive performance evaluation system such as the BSC that covers all aspects of bank activities encompasses internal and external environmental factors; growth and learning, and customer satisfaction would help Lebanese banks in establishing both financial and non-financial data to judge their performance.

\section{The Balanced Scorecard and Bank Performance}

The Balanced Scorecard was developed and designed by Kaplan and Norton in 1992. Kaplan and Norton thought that measuring the financial performance is not enough to affect the companies' ability to create value (Rillyan et al., 2016). It is a complementary strategic model that considers financial and non-financial measures, and translates the organizational mission and strategy into a collection of performance measures (Afande, 2013). This approach tends to reflect the need of a balance between traditional financial measures and other non-financial elements such as customers, internal business process, and learning and growth.

The BSC has been implemented by companies in both developed and developing economies cutting across various industries (Ibrahim, 2015). During the last two decades, Balanced Scorecard has been widely used 
for performance measurement in different disciplines (Epstein \& Wisner, 2001; Lawson et al., 2006; Idalina et al., 2007; luu et al., 2008). It has been observed that most of the successful organizations are adopting BSC (Silk, 1998; Malmi, 2001; Rigby, 2001; Fernandes et al., 2006). In addition, increased use of BSC can be seen in recent researches like the ones related to: in supply chain integration (Bhagwat \& Sharma, 2007; Chang, 2009), research and development projects (Eilat et al., 2008; Asosheh et al., 2010), university performance evaluation (Wu et al., 2011), and banks (Zhang \& Li, 2009; Abu Yahya, 2009; Al-Mawali et al., 2010; Abay, 2010; Umar \& Olatunde,2011; Najjar \& Kalaf, 2012; Dave \& Dave, 2012; Panicker \& Seshadri, 2013; Ombuna et al., 2013; Tominac, 2014; Tariq et al., 2014; Kumar, 2015; Visalakshi \& Kasilingam, 2015; Rostami et al., 2015; Akter, 2015; Kumar, 2016; Rillyan et al. 2016). According to Kuang-Hua (2005), BSC is the most influential managerial concept in the last 75 years.

Like other industries, banks can not only focus on the financial perspective. Since its appearance, the BSC has gained a widespread acceptance as a nuanced tool for performance measurement in various business sectors including the banking sector (Panicker \& Seshadri, 2013). The perspectives that are used in literature to measure performance at banks using the BSC encompassed those that were initially stated by Norton and Kaplan. These perspectives are: The Financial Perspective, the Customer Perspective, the Internal Business Process perspective, and the Learning and Growth Perspective. Some international banks have successfully utilized Balanced Scorecard in order to improve their performance (Rillyan et al., 2016). The banking sector has started adopting the Balance Scorecard to exhibit to stakeholders that this sector provides performance information regarding financial and non-financial measures. Currently, the BSC is deemed as one of the most common frameworks of measuring performance. During the last two decades, many studies and articles related to measuring performance of banks using the BSC model were published.

\section{Objectives of the Study}

1- To empower the Lebanese banks, academics and researchers to follow the steps of many other countries in the MENA region and to start practicing the BSC in a trial to improve the performance of banks and enhance economic growth in Lebanon.

2- To provide researchers with a variety of methods and measures used in previous studies to evaluate the performance of banks using the Balanced Scorecard.

3- To review the relevant literature related to the measure of banks' performance using the BSC model.

4- To contribute to the BSC literature on banks and provide a basis for future research.

\section{Relevance of the Study}

Now days, the gap between banks in developed and developing countries from one side and the Lebanese banks from the other side in terms of applying performance management systems (PMS) and non-financial measures to judge performance is huge. Lebanese banks must be pressure by the BDL and the ABL, and other governmental bureaus to start applying multidimensional performance measurement systems to compete and survive in contemporary competitive business environment. It is evident that the use of the balanced Scorecard as a bank's performance measure has gained more interest in recent years both in research and practice. This model provides answers for assessing the overall performance and competitiveness of banks. As for Lebanese banks, no empirical studies on performance using the Balanced Scorecard have been noticed. Consequently, the above mentioned gaps has attracted the researchers of this work to conduct this study.

\section{Review of Literature}

The review of literature states a strong relevance to appraising banks performance through the BSC approach. The BSC has gradually gained popularity in the United States right after 1992 (Gupta \& Sharma, 2016), then in Europe, Latin America and Australia (Janota, 2008). Since the start of the third millennium, 
many articles were published using the BSC as a measure of performance for banks in China, Indonesia, Pakistan, Ghana, Kenya, Jordan, India, Libya, Finland Sweden, Japan, and other countries in Africa and Asia (Akter, 2015; Gupta \& Sharma, 2016). However, the BSC- as a performance measure- did not find its way to Lebanon in general, and to the Lebanese Banking Sector, in particular.

In his article on "Balanced Scorecard Benefits: Nat West Bank", Ashton (1998) examined the National Westminster Bank of England. Researcher studied the benefits of using BSC model in improving the quality, speed, providing assistance to change the corporate culture from its rigid form and to control the structure based upon "empowerment and coaching". The Balance Scorecard helped Nat West Bank to overcome the traditional reliance on financial reporting with the aid of introducing a system, which takes a long-term understanding and involvement of many factors including innovation and learning. The bank considered the author's effort to be successful in terms of synchronizing performance management of the employees with the long terms goals of the bank and to enhance the ability of their organization for the successful business growth, allocation of its resources and in developing a consistent and easily understandable performance management system.

Davis and Albright (2004), in their quasi-experimental study entitled "An Investigation of the Effect of Balanced Scorecard Implementation on Financial Performance", examined whether or not bank branches implementing the Balanced Scorecard outperformed bank branches of same organization on measuring key financial problems. Researchers found a proof of better financial performance for those branches that are implementing BSC model as compared to those who are not using BSC model. The authors also concluded that the BSC method promoted an improved financial performance if non-financial measures were incorporated logically and systematically. The traditional financial performance measurement system focused solely on possible explanation and there was less coherent connection among the beleaguered financial measure of interest and the steps taken for the performance system.

Zhang and Li (2009) scrutinized commercial banks in China in their theoretical paper "Study on balanced Scorecard of Commercial Bank in Performance Management System". They selected BSC model as an instrument to enhance the performance of commercial banks. They concluded that the BSC model enhanced the authenticity of Performance Management Appraisal System depends upon the internal business processes, customer \& financial factors and employees' growth. Researchers recommended a particular strategy for the application in conjunction with the hurdles of BSC model. Moreover, updating the mode of banking services may also widen the area of financial services and improve the standards as well as the effectiveness of financial services.

Authors also recommended the formation of a governance mechanism for BSC, feedback procedures and goals assessment. In order to achieve such an innovative model, it is important to enhance 'Smile' (services, personal and incentive mechanism). The banking industry in China should also speed up the service delivery model for the acceleration of mixed services in order to enhance international effectiveness. The banking industry in China should speed up the transformation of service delivery model to accelerate the pace of mixed services to enhance international competitiveness.

Umar and Olatunde (2011), in their study "Performance Evaluation of Consolidated Banks in Nigeria by Using Non-Financial Measures", evaluated the performance of four consolidated banks in Nigeria. They identified 7 non-financial measures of bank performance out of 43 measures through factor analysis and assessed the overall performance of banks. The seven measures included IT, transaction cost, delivery service, quality, offerings by the bank, loan approval process and customer satisfaction. Researchers adopted simple random sampling technique to select the samples (customers of 4 Banks). Structured disguised questionnaires were used to collect the data from 303 customers. Barlitt test of Sphericity for testing hypothesis and Kaiser-Meyer-Olkin Method was used to check the sampling adequacy whereas multiple regression analysis technique was used to find the variation caused by non-financial measures. 
Researchers recommended that for improving the financial performances of joined banks, the identified seven non-financial measures should be implemented.

Dave and Dave (2012), in their research paper "Applying Balanced Scorecard in Indian Banking Sector: An Empirical Study of the State Bank of India", constructed a balanced scorecard model and evaluated the performance of the state Bank of India bank over twelve years (1997 - 2008) using 29 indicators of the bank. The study concluded that being a part of the service sector, long-term strategic planning in a bank needs to focus on a comprehensive performance evaluation system. BSC emerges as an efficient and allinclusive tool of encompassing various aspects of Banks' performance. It helps in understanding the complementarities among the various performance indicators of a bank and makes the design strategy and the implementation process more efficient. Implementing BSC technique becomes complicated due to the difficulties of measuring the intangible assets, Existence of interrelations between the identified indicators, the differences in assigned and various indicators in organization and the trouble in setting the linkages between an employee's performance and the reward mechanism.

Karasneh and Al-Dahir (2012) conducted an empirical study "Impact of IT-Balanced Scorecard on Financial Performance: An Empirical Study on Jordanian Banks" to examine the importance of BSC model as a performance measurement tool with IT incorporation in Jordanian banking sector. This model consists of five perspectives; internal business process, customer satisfaction, competitiveness and, learning \& growth by IT indicator developed in different perspectives. The sample of the study included 122 questionnaires filled through individual survey from 19 bank employees from the Jordanian Banking Sector and the results were analyzed through SPSS. It was concluded that a significant relationship exists between internal business procedure \& IT and strategic \& financial competitiveness but not among employees \& customers perspectives. Results indicated that the developed model in this research is definitely a promising tool for the firms to evaluate the performance. Based on the findings, the researchers encourage organizations to recognize the role of the (IT-BSC) as a performance measurement tool since they were able to develop a particular tool that can be used with maximum technological techniques. They recommended that for enhancing continuous improvement and job satisfaction among their employees, banks should give attention to their all employees and formulate those policies that can assist in taking right decisions. Banks are usually concerned in developing IT services to draw new customers, satisfy them and maintaining their loyalty. For this purpose, they should collect customer data through follow up services, emails and surveys.

Ombuna et al. (2013) carried out a study to examine the impact of Balanced Scorecard usage on the performance of commercial banks in Kenya. The study was conducted in Nakuru district of Kenya where convenient sampling was utilized to select 72 respondents from 18 commercial banks in Nakuru. A Likert scale of 1 to 5 was employed to gauge the degree of response in terms of strength or weakness. Descriptive statistics were employed to analyze the data and Pearson's correlation was utilized to test the relationship between 2 or more variables. Ombuna and his colleagues found that the usage of the BSC has a positive impact on the performance of banks, and they concluded a positive correlation between the BSC links to organization mission and strategy on the one hand and to the involvement of employees in implementing the BSC on the other hand. BSC provides feedback on the internal processes and external outcomes in order to continuously improve strategic performance and consequently results. Moreover, the study also concluded that the effectiveness of BSC uses depends on organization dynamics, the manner of execution and monitoring and evaluation procedures adopted. The authors recommended that banks need to develop these products and services that have a competitive advantage and which satisfy the needs of customers.

Raphael \& Man (2013) conducted a study entitled "Integrating Financial and Non- Financial Measures to Measure the Performance of Commercial Banks: Evidence from Tanzania" in order to assess the performance of different banks in Tanzania by using financial and non-financial methods. A sample of 21 banks was involved in the study which employed statistical tests and the one-way ANOVA. Financial Data were extracted from the annual reports of banks while non- financial data were gathered from BSC 
templates gathered from commercial banks and through surveys. The study concluded that on the whole, performances of commercial banks were at higher level in case of big foreign banks and comparatively low in big domestic banks. In other words, large foreign banks proved more efficient than their counterparts were specifically because the high performance of these commercial banks is due to their inveterate history of implementing BSC compared to the other banks.

Tominac (2014), in his research paper "Possibilities of Balanced Scorecard Application in Commercial Banks", investigated the BSC as a tool or methodology for managerial accounting. The aim of this study was to contribute to the understanding of how the Balanced Scorecard is developed, and how it is applied in banks in terms of their performance measurement. Tominac concluded that Financial Indicators are not enough for reporting because they are not directly connected with the bank's long-term goals. Balanced Scorecard engages all hidden resources in order to ensure a bank's leading position in the market. It is important for implementing Balanced Scorecard in banks to appropriately balance all imperatives of the bank. Applying BSC also helps management to consider the strengths and weaknesses, areas in which profits and losses are made. Implementation of BSC is expensive and it requires times and effort. It also helps bank employees to better understand the strategies.

Tariq et al. (2014), in their study "Investigating the Impact of Balanced Scorecard on Performance of Business: A Study Based on the Banking Sector of Pakistan", investigated the feasibility and efficiency of setting and implementing the BSC in enlightening the performance of an organization. Data was collected using the non-probability sampling technique using questionnaires which were filled by a sample of 400 professionals belonging to various banks at the middle level through a survey interview. The regression test and ANOVA were used to test the reliability and validity of the data series. This model has been developed based on five different perspectives, which include internal control, finance, learning and customers' visions and approach. They found that using the BSC model in banks provides favorable outcomes and improves banks' performance significantly. The findings also suggested that the financial, customer, internal process and learning and growth perspectives have a remarkable contribution in improving the banks' overall performance whereas the role of the vision and strategy perspective is insignificant. Moreover, the study concluded a great influence of the financial perspective on the banks' performance. The outcome of this study helps in providing a framework and highlights the status of applying the BSC in banking sector.

Ibrahim (2015) conducted a study entitled "Investigating the Use of the Four Perspectives of Balanced Scorecard (BSC) as a Technique for Assessing Performance by Nigerian Banks". This study was carried out in an attempt to discover the use of BSC as a tool for measuring the performance of Nigerian banks. It is intended to fill a gap concerning the little attention to the use of BSC in Nigeria. The concepts of performance and its measurements, financial and non-financial measures of performance and the concept of BSC have been discussed. The preliminary population of the study encompassed 21 banks operating in Nigeria, and the use of a judgmental/purposive sampling technique reduced the sample to eleven banks. To collect data, a survey technique using questionnaires was used. The descriptive statistics and KruskalWallis ANOVA and descriptive statistics have been used to analyze the data. The study concluded that Nigerian banks depend on financial and customer performance measures as a technique to assess their performance. A comprehensive view of the performance of Nigerian banks cannot be assured without incorporating all the four perspectives of BSC. Ibrahim recommended that Nigerian banks should improve their performance measurement systems by harmonizing their performance measures within the four views of BSC.

Akter (2015) conducted a study entitled "Exploring the Scope of Adopting Multidimensional Performance Measurement Models in Banking Sector of Bangladesh" to contribute to the evolution of the banking sector of Bangladesh by investigating the scope of adoption of multidimensional performance measurement models. The sample of the study encompassed branches of 19 selected commercial banks in Bangladesh. An opinion survey was conducted to collect the data on usage of performance measures. Thirty 
performance measures from different performance areas were chosen after consultation with bank professionals. Cronbach's alpha and SPSS were used by the researcher to assess the reliability and to analyze the collected data respectively. The study found that banks in Bangladesh are considering nine performance factors (identified through factor analysis) to judge their overall performance. The factors are Market Indicator, HRM, Effectiveness of Internal Processes, Marketing Strategy Implementation, Adaptability to Changes, Customer Perception, Efficiency of Management, Earning Capacity and Social Change. Based on the results, it was concluded that there might have been a scope of adoption of multidimensional performance measurement models.

Rillyan et al. (2016), in their research study "A study on Linkages among Balanced Scorecard Perspectives: The Case of Indonesian Local Banks" analyzed the most effective variables of the Balanced Scorecard to achieve a strategic objective established by a local bank in Indonesia. They only found 17 strategic variables that significantly influenced banks' performance and profitability. Stepwise regression analysis was performed to investigate and compare the relationships among the variables from the corporate strategy which was composed by the four perspectives of BSC and represent every existing division in the company. This regression test assessed any direct effects of each of the perspectives and compared the relative strength of the relationships among the four BSC perspectives. The results of this study proved that there is a strong relationship among the BSC perspectives proposed in the Corporate Strategy of the local bank.

Kumar (2016) conducted a study entitled "Awareness Regarding Contemporary Performance Measures for Measuring Performance of Indian Banking Sector". Primary data was collected through structured questionnaires. A sample of 200 bankers, 100 each from public and private sector banks was drawn. Data was analyzed by using simple frequencies, percentages, averages, weighted average scores, Mann- Whitney test, etc. The study concluded that both financial and non-financial measures are considered important by public and private sector banks for measuring their performance but a balance between the two measures is needed. It was found that bankers from the public sector are more aware of various performance measurement systems under financial measures as compared to private sector banks while under nonfinancial measures, bankers from both sectors are equally aware of various performance measurement systems.

Abu Yahaya (2009) - in his research project - "Using Balanced Scorecard to Assess Performance of Banks in Ghana" concluded that the perspectives of the customer, internal business and learning may disturb the performance of the banks up to high extent in Ghana. Abu Yahaya found that the well performing banks based on financial measures might not only be the best banks in the particular sector when other dimensions should be considered. This study presents additional information regarding the performance of banks. Such information enables banks to focus on the basic strategies to deliver superior values and came back to shareholders. For this purpose, primary and secondary sources were used for data collection. Primary sources encompassed questionnaires and interviews that concentrated on the internal processes and learning and growth perspectives whereas secondary sources included banks published financial statements. The author recommended that banks must implement the BSC model as a performance measurement tool in order to enhance the profitability margin. Banks should follow a well-planned methodology to harvest the full benefit of their investment.

Wu et al. (2009) evaluated banking performance based on the Balanced Scorecard. They used "A Fuzzy MCDM Approach Scorecard", and identified 23 evaluation indexes from 55 indexes appropriate for banking performance with reference to BSC perspective through expert opinions. They were able to rank them in terms of their relative importance. The customer perspective came first, followed by the finance perspective, and then by learning \& growth and the internal process using FAHP process. Customer satisfaction, ROA, EPS, customer retention rate and profit per customer were found as top five evaluation indexes. $\mathrm{U}$ bank, $\mathrm{C}$ Bank and $\mathrm{S}$ bank respectively were ranked on the basis of performance using MCDM 
analytical methods. They suggested that there is no one particular performance evaluation index that can be used for all banks.

Al-Mawali, et al. (2010), in their research paper "Balanced Scorecard (BSC) Usage and Financial performance of Branches in Jordanian Banking Industry", investigated empirically multiple performance measures and their effects on the economic performance of banks at branch level. Jordanian banks in the branches level. The entire banks under the Jordanian banking industry were taken as a population size which includes 480 branches out of which 120 branches were selected on random basis as a sample. Questionnaires were framed for the collection of data. To test the effect of BSC, Multi-Dimensional Regression analysis was done. The authors found that there is a positive relationship between the branches of financial performance and the overall BSC measures usage. However, the results of this study show that the usage of non-financial measures, such as customer-oriented indicators and product-oriented indicators seem important to enhance the performance of the organization. Findings of the study show that there is a positive relationship among multiple performance measures using BSC models and financial performance at the level of branches.

Abay (2010), conducted a research work titled "Performance Evaluation of Selected Ethiopian Commercial Banks Using Balance Scorecard". The purpose of this study was to assess the performances of the selected Ethiopian commercial banks by the help of BSC as a framework. Both qualitative and quantitative research techniques were applied in this research to collect the data in the form of questionnaires and annual reports. To analyze the data, SPSS and descriptive statistics technique were used. The study suggested that BSC framework could be used to assess the performance of the banks in case of Ethiopia. It can also assist managers, shareholders in seven different dimensions. Results of the study demonstrated that there is strong relationship exists between financial performance and non-financial performance measures. It is suggested in the research that non-financial measures are more explanatory factors for financial performance. Study also proved cause and effect relationship between the identified measures.

Shaverdi el al. (2011) conducted a study "Combining Fuzzy MCDM with BSC Approach in Performance Evaluation of Iranian Private Banking Sector" to assess the performance of three nongovernmental Iranian banks. 21 performance indicators were selected as the proper banking performance indexes according to BSC perspectives. A Fuzzy Analytic Hierarchy Process (FAHP) was used to weigh each of the chosen indicators. The study concluded that the ranking order of banking performance was as follows: The Customer Perspective, the Finance Perspective, the Internal Process Perspective, and the Learning and Growth Perspective respectively. The top five ranking indicators are: customer satisfaction (Customer Perspective), ROA (Financial Perspective), customer retention (Customer Perspective), EPS (Financial Perspective), and profit per customer (Customer Perspective) correspondingly.

Najjar and Kalaf (2012), in their case study "Designing a Balanced Scorecard to Measure a Bank's Performance: A Case Study”, measured the performance of a large Iraqi bank using the BSC method. Data was collected for four years and a BSC model was constructed, including 20 measures. The analysis helped the cause and effect relationship between the financial and the non-financial dimensions of BSC. The bank's management realized the importance of BSC as a tool to develop strategies and performance management system. Top management of the bank should demonstrate its commitment in adopting BSC for its successful implementation. The authors recommended that future researches in Iraqi banking sector are necessary and such studies should focus in examining liable factors that can facilitate the implementation of BSC models. They also said that further studies are needed to identify the pertinent measures of the BSC to the Banking Sector.

Wu (2012), in his article "Constructing a Strategy Map for Banking Institutions with Key Performance Indicators of the Balanced Scorecard”, presented a structured assessment methodology to link performance indicators (KPIs) with a strategy map of the BSC for banking sector. The Decision-Making Trial and Evaluation Laboratory (DEMATEL) method were used to determine the causal relationship and strengths 
of influence among the KPI's, to examine critical and influential factors and to develop a visualize strategy with logics in improving banks' performance. The study revealed that Customer Satisfaction, Sales Performance and Customer Retention rate as the three most essential evaluation indicators of banking performance. The results suggested that although the presented approach is deemed to be feasible and objective, the strategy maps developed are not universal and they cannot fit all scenarios. Hence, performance indicators should be tailored according to objectives of each individual unit to meet the goals of the organization.

In their study, "Devising a Balanced Scorecard to Determine Standard Chartered Bank's Performance: A Case Study", Panicker and Seshadri (2013) displayed how to use the Balanced Scorecard (BSC) as a tool that can be applied in commercial banks' performance management system. A Balanced Scorecard model including 20measures was constructed to measure the standard chartered Banks' Performance, using the case study approach.

Utilizing the concepts of Kaplan and Norton, financial and non-financial data was derived to measure the performance of the assumed foreign bank during the period 2009-2012. The study focused on the importance of examining performance from different perspectives including financial perspective as well. BSC is widely used in banking sector of India. This study recommended that more studies are needed to identify the relevant measures of the BSC to the Banking Sector.

In their study "Bank's Performance Evaluation Model on the Balanced Scorecard Approach, Fuzzy DEMATEL and Analytic Network Process", Eskandari et al. (2013) presented a structural evaluation methodology to link Key Performance Indicators (KPIs) into a strategy map of the Balance Scorecard for banking institutions. 23 KPIs for banking were chosen for the four perspectives of the Balanced Scorecard. The Fuzzy Decision-Making Trial and Evaluation Laboratory (FDEMATEL) method, a multiple criteria analysis tool, was then employed to determine the causal relationships between the KPIs.

Each of the four perspectives of the BSC was deemed as a cluster, and each indicator (KPI) was considered as a mode in a cluster. The customer perspective was ranked first, then the financial perspective. The internal process perspective was ranked third while the learning and growth perspective was ranked fourth. The study concluded that the three most essential KPIs for banking performance are customer satisfaction (customer perspective), sales performance (internal process perspective), and customer retention rate (customer perspective).

Ozturk \& Coskun (2014), in their article "A Strategic Approach to Performance Management in Banks: The Balanced Scorecard", provided the literature with a theoretical background on the application of BSC model on strategic performance management in the banking industry. The main objective of the study was to expose the BSC practices in literature. The authors concluded that BSC is a comprehensive method to offer quality and efficient financial services. It is important to adopt new ideas in the banking sector especially for international competitiveness. They also found that it is highly important to prepare BSC for the banks rather than to report financial performance in terms of evaluating performance only.

Rostami et al. (2015), in their article "Defining Balanced Scorecard in Banking Industry Using FAHP Approach", examined the four perspectives of the BSC model and their importance. To achieve the research objectives, Fuzzy Analytical Hierarchy Process (FAHP) was used. Initially, 56 indicators were found by expert opinions through administering a questionnaire but at the end, 09 indicators were found out. In the second stage, the weight of each indicator was examined using a pair comparison questionnaire based on the FAHP approach.

The findings of the study ranked customer perspective as the first cluster and financial perspective as the second, internal processes perspective as the third and the learning and growth perspective as the fourth in the balanced scorecard model. It was found that the "market rate" and the "growth rate of customer 
complaints" and "customer attract rate" are the most important indicators of customer aspect. "Revenues", "P/E ratio" and "leverage" are the most important indicators of the financial aspect. The "electronic transaction share", "performance management" and "research and development costs" are the most important indicators in the internal processes aspect whereas "employee stability", "loan per capita" and "present reduction in disciplinary matters" are the most important indicators in the learning and growth aspect.

Kirandeep (2015) conducted a research project entitled "The Application of Balanced Scorecard as a Strategic Management Tool at National Bank of Kenya" to identify the extent of the adoption of the BSC at the National Bank of Kenya and the challenges involved in the adoption of the Balanced Scorecard. The study employed a case study design to examine the presentation of BSC as a strategic management tool at the National Bank of Kenya (NBK). Primary data was collected through in-depth interviews with 19 employees at different managerial levels. Secondary data was also obtained from the banks' strategic plan, performance development articles, and the official website of NBK.

This study found out that applying the balanced scorecard as a strategic management tool has greatly influenced strategy formulation and implementation at the National Bank of Kenya. The most important factor is that the BSC has improved the understanding of strategy in the organization. The BSC provides guidance for action. Challenges faced in adopting the BSC included insufficient skills and knowledge of the BSC, cultural changes which lead to confusion in bank and having KPI's that are too problematic when staff performance is appraised departmentally. The author suggested that all the above-mentioned issues should be taken into deliberation by any organization when adopting the BSC as a strategic management tool.

Abofaied (2017) conducted a study entitled "Evaluation of Bank's Performance by Using Balanced Scorecard: Practical Study in Libyan Environment". The aim of the study was to increase the understanding of how the Balanced Scorecard is established and implemented to evaluate the performance of a Libyan bank. The study employed the case study approach, and a BSC model has been constructed including 20 indicators to examine the performance of the assumed bank between 2007 and 2010. The analysis helped in examine cause and effect relationships between financial and non-financials areas as performance measurement.

The study concluded that the bank is still concentrating on the financial performance as a measure of performance. The internal process perspective and the learning and growth perspective revealed no significant improvements. The scores of the customer perspective were the worst with zero average annual growth during the period of the study. This research highlighted the status of viewing performance from other perspectives in addition to the financial perspective.

Due to less work in this area in Libya, this study will contribute to the knowledge of how banks in Libya may apply the BSC to measure their performance. The author suggested that future researches in the banking sector in Libya in this domain are needed, and thus he considered this study as a trigger for policy makers and bankers to start using the BSC.

\section{Indicators and Measures used in Balanced Scorecard Models}

To measure the performance of banks using the Balanced Scorecard, researchers have used different methods and a variety of indicators. Finding the proper performance indicators that can fit the needs of all experts and organizations does not seem an easy task. Every researcher has tailored his own BSC model depending on the objectives of the study, the availability of data and other constraints. A vast array of literature is available on Balanced Scorecard methods and performance indicators. The most commonly used methods and indicators in studies related to Balanced Scorecard at banking are listed below. 
Table 1: Methods \& Measures used in Studies Related to Banks Performance Using the Balance Scorecard.

\begin{tabular}{|c|c|c|c|c|c|}
\hline \multirow[t]{2}{*}{ Author(s) } & $\frac{\text { Method }}{\text { Used }}$ & \multicolumn{4}{|c|}{$\underline{\text { Measures }}$} \\
\hline & & $\begin{array}{c}\text { Financial } \\
\text { Perspective }\end{array}$ & $\begin{array}{c}\text { Customer } \\
\text { Perspective }\end{array}$ & Internal Process & Learning \& Growth \\
\hline $\begin{array}{l}\text { Abofaied } \\
\text { (2017) }\end{array}$ & Case Study & $\begin{array}{l}\text { Liquidity } \\
\text { ratio } \\
\text { - } \text { ROI \& ROE } \\
\text { - Profit Margin } \\
\text { - Leverage } \\
\text { ratio }\end{array}$ & $\begin{array}{l}\text { - } \text { Customer } \\
\text { satisfaction } \\
\text { - Customer } \\
\text { growth } \\
\text { - Growth of } \\
\text { current } \\
\text { accounts } \\
\text { - Growth of } \\
\text { saving } \\
\text { accounts } \\
\text { - Growth of } \\
\text { safety deposits }\end{array}$ & $\begin{array}{l}\text { - Productivity } \\
\text { growth } \\
\text { - Growth of } \\
\text { banking } \\
\text { services } \\
\text { - Credit growth } \\
\text { - Growth in the } \\
\text { software } \\
\text { application } \\
\text { - Front office } \\
\text { employees }\end{array}$ & $\begin{array}{l}\text { - Employee productivity } \\
\text { - Employee turnover } \\
\text { - Growth of the bank } \\
\text { branches } \\
\text { - Employee participation } \\
\text { in development } \\
\text { programs } \\
\text { - Number of employees } \\
\text { using IT in their work }\end{array}$ \\
\hline $\begin{array}{l}\text { Najjar \& } \\
\text { Kalaf } \\
(\mathbf{2 0 1 2})\end{array}$ & Case Study & $\begin{array}{l}\text { - } \begin{array}{l}\text { Liquidity } \\
\text { ratio }\end{array} \\
\text { - } \text { ROI \& ROE }\end{array}$ & $\begin{array}{l}\text { - Customer } \\
\text { satisfaction } \\
\text { - Customer } \\
\text { growth } \\
\text { - Growth of } \\
\text { current } \\
\text { accounts } \\
\text { - Growth of } \\
\text { saving } \\
\text { accounts } \\
\text { - Growth of } \\
\text { safety deposits }\end{array}$ & $\begin{array}{l}\text { - Productivity } \\
\text { growth } \\
\text { - Growth of } \\
\text { banking } \\
\text { services } \\
\text { - Credit growth } \\
\text { - Growth in the } \\
\text { software } \\
\text { application } \\
\text { - Front office } \\
\text { employees }\end{array}$ & $\begin{array}{l}\text { - Employee productivity } \\
\text { - Employee turnover } \\
\text { - Growth of the bank } \\
\text { branches } \\
\text { - Employee participation } \\
\text { in development } \\
\text { programs } \\
\text { - Number of employees } \\
\text { using IT in their work }\end{array}$ \\
\hline $\begin{array}{l}\text { Panicker } \\
\text { \& } \\
\text { Seshadri } \\
(\mathbf{2 0 1 3})\end{array}$ & Case Study & $\begin{array}{l}\text { - Liquidity } \\
\text { ratio } \\
\text { - } \text { ROI \& ROE } \\
\text { - } \begin{array}{l}\text { Net profit } \\
\text { margin }\end{array} \\
\text { - Leverage } \\
\text { ratio }\end{array}$ & $\begin{array}{l}\text { - Customer } \\
\text { complaints } \\
\text { redressed } \\
\text { - Growth in } \\
\text { customer } \\
\text { saving } \\
\text { accounts } \\
\text { - Growth in the } \\
\text { term deposit } \\
\text { - Growth in the } \\
\text { demand } \\
\text { deposit } \\
\text { - Customer } \\
\text { banking net } \\
\text { promoter score }\end{array}$ & 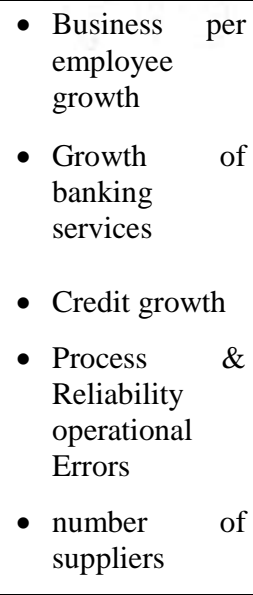 & $\begin{array}{l}\text { - profit per employees } \\
\text { - \% of employees } \\
\text { appraised } \\
\text { - \% of employees } \\
\text { receiving training }\end{array}$ \\
\hline $\begin{array}{l}\text { Tominac } \\
(\mathbf{2 0 1 4 )}\end{array}$ & Case Study & $\begin{array}{l}\text { - } \mathrm{ROE} \& \text { ROA } \\
\text { - Net interest } \\
\text { margin } \\
\text { - Revenue mix }\end{array}$ & $\begin{array}{l}\text { - } \text { Market share } \\
\text { - Customer } \\
\text { satisfaction } \\
\text { - Customer } \\
\text { acquisition }\end{array}$ & $\begin{array}{l}\text { - Error rates } \\
\text { - Investment in } \\
\text { technology } \\
\text { - Number of } \\
\text { complaints }\end{array}$ & $\begin{array}{l}\text { - Revenue from new } \\
\text { products } \\
\text { - Product development } \\
\text { cycle } \\
\text { - Employee survey }\end{array}$ \\
\hline
\end{tabular}




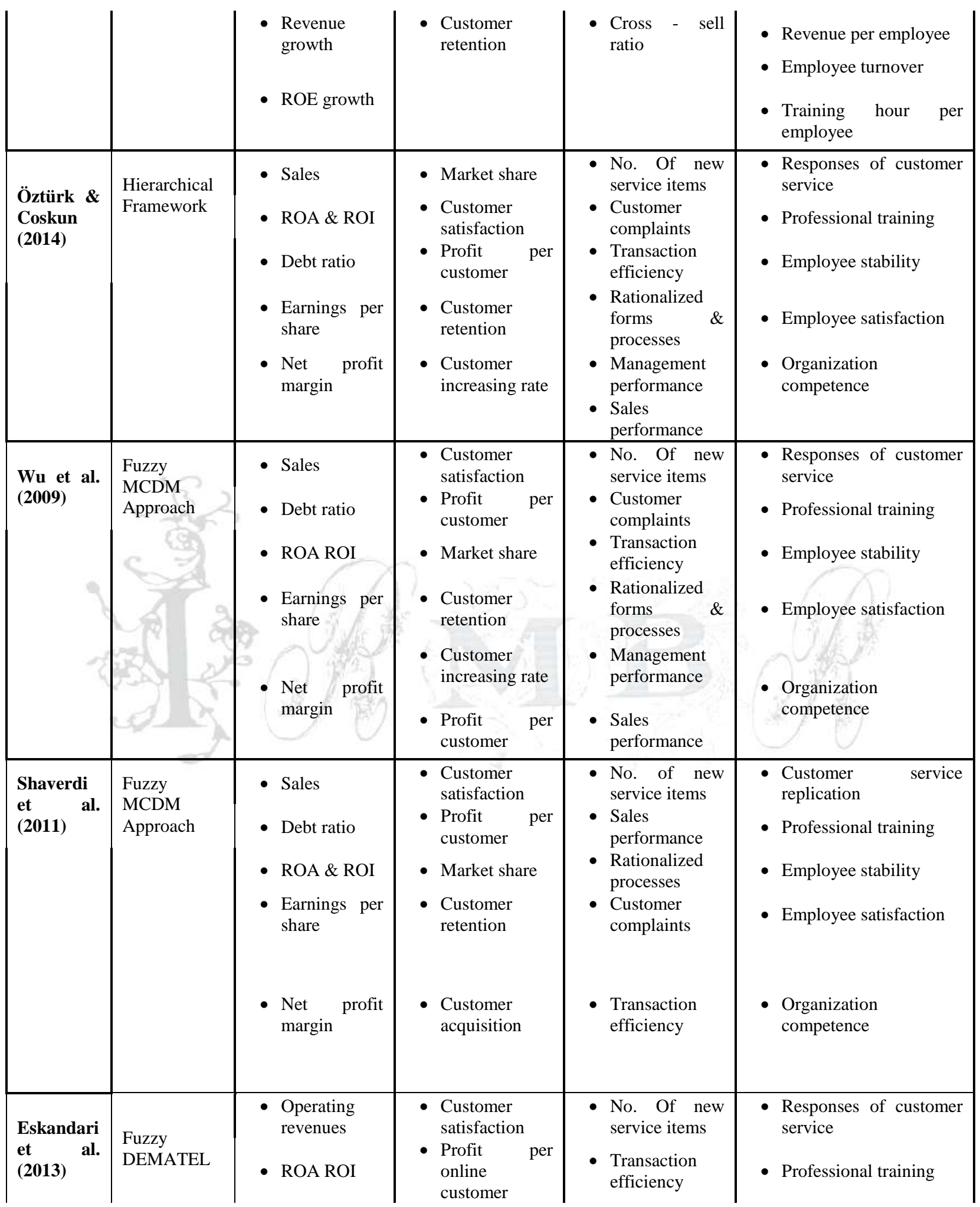




\begin{tabular}{|c|c|c|c|c|c|}
\hline & & $\begin{array}{l}\text { - Debt ratio } \\
\text { - Earnings per } \\
\text { share }\end{array}$ & $\begin{array}{l}\text { - Market share } \\
\text { - Profit per } \\
\text { customer } \\
\text { - Customer } \\
\text { retention } \\
\end{array}$ & $\begin{array}{l}\text { - Rationalized } \\
\text { forms \& } \\
\text { processes } \\
\text { - Management } \\
\text { performance } \\
\text { - Sales } \\
\text { performance } \\
\end{array}$ & $\begin{array}{l}\text { - Employee stability } \\
\text { - Employee satisfaction } \\
\text { - Organization } \\
\text { competence } \\
\end{array}$ \\
\hline $\begin{array}{l}\text { Al- } \\
\text { Mawali et } \\
\text { al. (2010) }\end{array}$ & $\begin{array}{l}\text { Multiple } \\
\text { Regression }\end{array}$ & $\begin{array}{l}\text { - Branch profit } \\
\text { - Product } \\
\text { profitability } \\
\text { - Return on net } \\
\text { assets } \\
\text { - Return on } \\
\text { assets } \\
\text { - Branch } \\
\text { operating } \\
\text { costs }\end{array}$ & $\begin{array}{l}\text { - Customer } \\
\text { satisfaction } \\
\text { - Customer } \\
\text { acquisition } \\
\text { - Customer } \\
\text { retention } \\
\text { - Customer } \\
\text { complaints } \\
\text { - Customer } \\
\text { loyalty }\end{array}$ & $\begin{array}{l}\text { - Staff turnover } \\
\text { - Employee } \\
\text { training and } \\
\text { development } \\
\text { - Employee } \\
\text { productivity } \\
\text { - Absenteeism } \\
\text { promotion } \\
\text { - Employee } \\
\text { satisfaction }\end{array}$ & $\begin{array}{l}\text { - Profit by the product / } \\
\text { service } \\
\text { - Number of transactions } \\
\text { - Cost per product / } \\
\text { service } \\
\text { - New product / service } \\
\text { - Profit by the product / } \\
\text { service }\end{array}$ \\
\hline $\begin{array}{l}\text { Abu } \\
\text { Yahya } \\
(2009)\end{array}$ & $\begin{array}{l}\text { Descriptive } \\
\text { Statistics }\end{array}$ & - $\mathrm{ROA}$ & $\begin{array}{l}\text { - } \text { Customer } \\
\text { satisfaction } \\
\text { index } \\
\text { - Customer } \\
\text { retention } \\
\end{array}$ & $\begin{array}{l}\text { - Sla for an } \\
\text { account } \\
\text { opening } \\
\text { - Sla for cash } \\
\text { withdrawal } \\
\text { - Sla for loan } \\
\text { disbursement }\end{array}$ & $\begin{array}{l}\text { - Employee satisfaction } \\
\text { index } \\
\text { - Employee } \\
\text { innovativeness } \\
\text { - Employee stability } \\
\text { index }\end{array}$ \\
\hline $\begin{array}{l}\text { Rostami } \\
\text { et al. } \\
(2015)\end{array}$ & $\begin{array}{l}\text { FAHP } \\
\text { Approach }\end{array}$ & $\begin{array}{l}\text { - Revenues } \\
\text { - Leverage } \\
\text { - Loan } \\
\text { - Assets } \\
\text { - ROE } \\
\text { - Spread Rate } \\
\text { - NPL } \\
\text { - Deposits }\end{array}$ & $\begin{array}{l}\text { - Market rate } \\
\text { - Growth rate of } \\
\text { customer } \\
\text { complaints } \\
\text { - Attract } \\
\text { customer rate } \\
\text { - Validity and } \\
\text { reliability } \\
\text { - Loyalty } \\
\text { - Long term } \\
\text { deposit } \\
\text { - availability } \\
\text { - Update } \\
\text { - Customer } \\
\text { satisfaction }\end{array}$ & $\begin{array}{l}\text { - Bank's share of } \\
\text { electronic } \\
\text { transactions } \\
\text { - Management } \\
\text { performance } \\
\text { - Research and } \\
\text { development } \\
\text { costs } \\
\text { - Number of } \\
\text { new services } \\
\text { and products } \\
\text { - Number of } \\
\text { issued cards } \\
\text { - Trying to } \\
\text { create a new } \\
\text { branch } \\
\text { - Bank's share of } \\
\text { consolidated } \\
\text { revenue } \\
\text { - Macro and } \\
\text { associated } \\
\text { facilities }\end{array}$ & $\begin{array}{l}\text { - Employee stability } \\
\text { - Loan per capita } \\
\text { - Present reduction in } \\
\text { disciplinary matters } \\
\text { - Education } \\
\text { - Training } \\
\text { - Deposits per capita } \\
\text { - Knowledge } \\
\text { management } \\
\text { - Experience }\end{array}$ \\
\hline
\end{tabular}




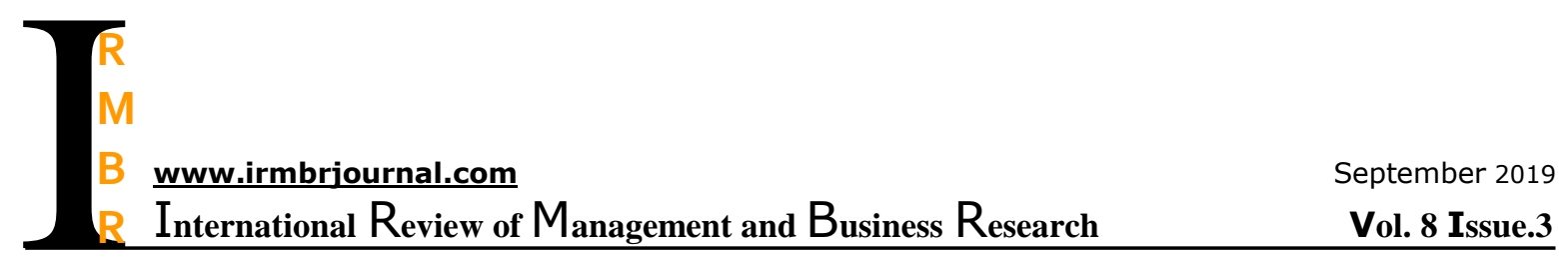

\begin{tabular}{|c|c|c|c|c|c|}
\hline $\begin{array}{l}\text { Abay } \\
(\mathbf{2 0 1 0})\end{array}$ & Regression & $\begin{array}{l}\text { - Net profit } \\
\text { growth } \\
\text { - ROE } \\
\text { - ROA }\end{array}$ & $\begin{array}{l}\text { - } \text { Customer } \\
\text { satisfaction } \\
\text { - } \text { Customer } \\
\text { retention } \\
\text { - Customer } \\
\text { intention } \\
\end{array}$ & $\begin{array}{l}\text { - } \begin{array}{l}\text { Transaction } \\
\text { speed }\end{array} \\
\text { - Service } \\
\text { responsiveness } \\
\text { - Service quality } \\
\text { \& diversity }\end{array}$ & $\begin{array}{l}\text { - Payment satisfaction } \\
\text { - Social relationship } \\
\text { - Work environment } \\
\text { participation }\end{array}$ \\
\hline $\begin{array}{l}\text { Raphael } \\
\text { \& Man } \\
(\mathbf{2 0 1 3})\end{array}$ & $\begin{array}{l}\text { ANOVA } \\
\text { Test }\end{array}$ & $\begin{array}{l}\text { - Operating } \\
\text { Efficiency } \\
\text { - NPL/Assets } \\
\text { - Liquidity } \\
\text { - NII/ Interest } \\
\text { exp. } \\
\text { - Return on } \\
\text { Average } \\
\text { asset }\end{array}$ & $\begin{array}{l}\text { - Interest } \\
\text { income/ total } \\
\text { income } \\
\text { - Gross loan/ } \\
\text { deposits } \\
\text { - HHI index }\end{array}$ & $\begin{array}{l}\text { - Response time } \\
\text { - Production of } \\
\text { timely service } \\
\text { - producing a } \\
\text { timely report } \\
\text { - Accuracy of } \\
\text { handling } \\
\text { transactions }\end{array}$ & $\begin{array}{l}\text { - Learn portfolio per } \\
\text { employee } \\
\text { - Income per employee } \\
\text { - Employee income to } \\
\text { employee portfolio }\end{array}$ \\
\hline $\begin{array}{l}\text { Adhiambo } \\
\text { (2014) }\end{array}$ & $\begin{array}{l}\text { Case Study } \\
\text { (Longitudinal } \\
\text { / Time Series } \\
\text { Analysis) }\end{array}$ & $\begin{array}{l}\text { - Profits } \\
\text { - Interest rates }\end{array}$ & - Competition & - Technology & $\begin{array}{l}\text { - Level of education } \\
\text { - Economic growth }\end{array}$ \\
\hline
\end{tabular}

Source: Respective sources, tabulation by the Authors

The table below (2) summarizes measures used by authors listed in the previous table

Table 2: List of Measures used in Banks' Performance Using the Balanced Scorecard

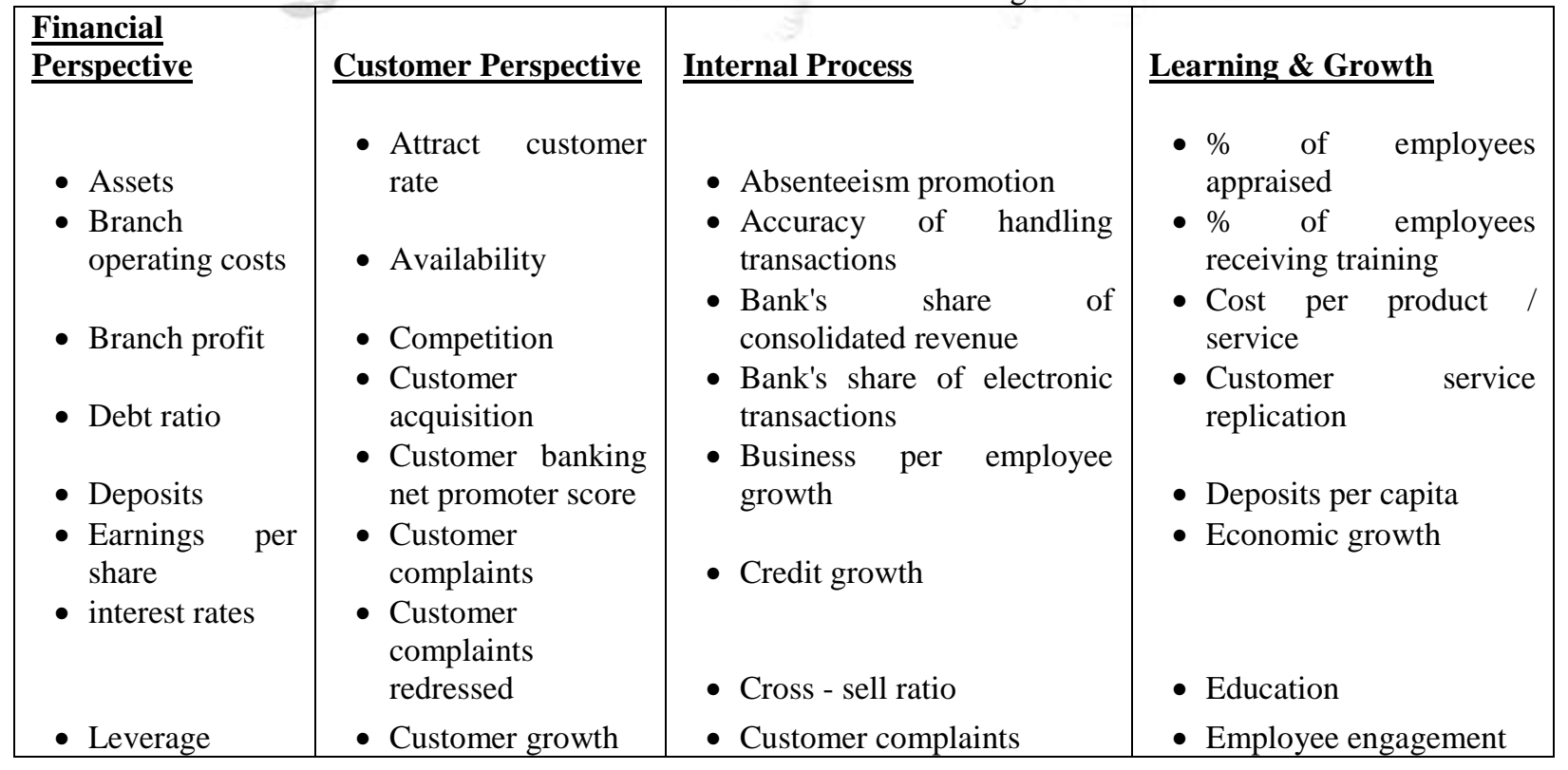




\begin{tabular}{|c|c|c|c|}
\hline 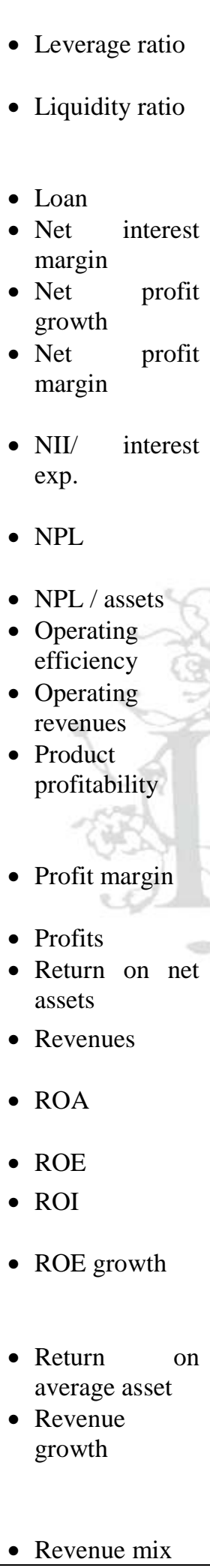 & $\begin{array}{l}\text { - Customer loyalty } \\
\text { - Customer retention } \\
\text { - Customer } \\
\text { satisfaction } \\
\text { - Gross } \\
\text { deposits } \\
\text { - Growth in } \\
\text { customer saving } \\
\text { accounts } \\
\text { - Growth in demand } \\
\text { deposit } \\
\text { - Growth in term } \\
\text { deposit } \\
\text { - Growth of current } \\
\text { accounts } \\
\text { - Growth of safety } \\
\text { deposits } \\
\text { - Growth of saving } \\
\text { accounts } \\
\text { - Growth rate of } \\
\text { customer } \\
\text { complaints } \\
\text { - HHI index } \\
\text { - Interest income/ } \\
\text { total income } \\
\text { - Long term deposit } \\
\text { - Loyalty } \\
\text { - Market rate } \\
\text { - Market share } \\
\text { - Profit per customer } \\
\text { - Profit per online } \\
\text { customer } \\
\text { - Update services } \\
\text { - Validity } \\
\text { reliability } \\
\text { - }\end{array}$ & $\begin{array}{l}\text { - Growth of banking services } \\
\text { - Growth of banking services } \\
\text { - Investment in technology } \\
\text { - Macro and associated } \\
\text { facilities } \\
\text { - Management performance } \\
\text { - No. Of new service items } \\
\text { - Number of complaints } \\
\text { - Number of issued cards } \\
\text { - Number of new services } \\
\text { and products } \\
\text { - Number of suppliers } \\
\text { - Process \& reliability } \\
\text { operational errors } \\
\text { - Production of timely } \\
\text { service } \\
\text { - Producing timely report } \\
\text { - Productivity growth } \\
\text { - Rationalized forms \& } \\
\text { processes } \\
\text { - Rationalized processes } \\
\text { - Research and development } \\
\text { - Rests }\end{array}$ & $\begin{array}{l}\text { - Employee survey } \\
\text { - Employee turnover } \\
\text { - Experience } \\
\text { - Growth of the bank } \\
\text { branches } \\
\text { - Income per employee } \\
\text { - Knowledge management } \\
\text { - Level of education } \\
\text { - Learn portfolio per } \\
\text { employee } \\
\text { - Loan per capita } \\
\text { - New product / service } \\
\text { - Number of employees } \\
\text { - Number of employees } \\
\text { using IT in their work } \\
\text { - Number of transaction } \\
\text { - Organization } \\
\text { competence } \\
\text { - Payment satisfaction } \\
\text { - Present reduction in } \\
\text { disciplinary matters } \\
\text { - Product development } \\
\text { cycle } \\
\text { - Professional training } \\
\text { - Profit by product / } \\
\text { service }\end{array}$ \\
\hline
\end{tabular}




\begin{tabular}{|c|c|c|}
\hline $\begin{array}{l}\text { - Sales } \\
\text { - Spread rate }\end{array}$ & $\begin{array}{l}\text { - Service quality \& diversity } \\
\text { - Service responsiveness } \\
\text { - Service level agreement for } \\
\text { account. Opening, cash } \\
\text { withdrawal, loan } \\
\text { disbursement } \\
\text { - Staff turnover } \\
\text { - Technology } \\
\text { - Transaction efficiency } \\
\text { - Transaction speed } \\
\text { - Trying to create a new } \\
\text { branch }\end{array}$ & $\begin{array}{l}\text { - Profit per employees } \\
\text { - Responses of customer } \\
\text { service } \\
\\
\text { - Revenue from new } \\
\text { products } \\
\text { - Social relationship } \\
\text { - Training } \\
\text { - Training hour per } \\
\text { employee } \\
\text { - Work environment } \\
\text { participation }\end{array}$ \\
\hline
\end{tabular}

Source: Tabulation by the Authors

\section{Conclusion}

The review of literature states a strong significance to appraising the performance of banks through the Balanced Scorecard, but unfortunately, no evidence has been found in terms of an academic project or a research material for applying the Balanced Scorecard to Lebanese banks. Additionally, the performance measurements used at Lebanese banks are still based on financial measures, and monthly and annual reports. The sole dependence of Lebanese banks on financial measures is considered deceptive because it does not provide a general view about how banks are doing regarding the internal processes, customers, and learning and growth. Empirical studies show that banks that are performing well financially are not the best banks when the other perspectives of the BSC are taken into consideration, and the implementation of Balanced Scorecard model provides favorable outcomes. Consequently, identifying the best performing banks and providing additional non-financial information regarding performance to all stakeholders, requires

The adoption of the BSC is a comprehensive and reliable strategic performance measurement tool. This study presents the most common measures used in previous studies to measure performance using the BSC. Choosing among these measures, or simultaneously working toward identifying the most relevant measures is one of the tasks that future research may concentrate on.

\section{References}

Abay, S. (2010). Performance Evaluation of Selected Ethiopian Commercial Banks Using Balanced Scorecard. Department of Accounting and Finance, College of Business and Economics, Mekelle Universiy . Mekelle, Ethiopia .

Abofaied, A. (2017). Evaluation of Bank'sPerformance by Using Balanced Scorecard: Practical Study in Libyan Environment. International Journal of Business and Management, Vol.V, No.1, 1-14.

Afande, O. (2013). Effects of Strategic Management Practicies on Performance of Financial Institutions in Kenya: A Case of Kenya Post Office Savings Banks. International Journal of Business Management and Administration.

Akter, S. (2015). Exploring the Scope of Adopting Multidimensional Performance Measurement Models in Banking Sector in Bangladesh. Journal of Business and Management (IOSR-JBM), Vo. 17, Issue 2. Ver.II, 25-34. 
Al-Mawali,H., Zainuddin,Y., \& Ali,N. (2010). Balanced Scorecard (BSC) Usage and Financial Performance of Branches in Jourdanian Banking Industry. International Scholarly and Scientific Research \& Innovation, 4(6), 1161-1168.

Al-Najjar,S.M., \& Kalaf,M. (2012). Designing a Balanced Scorecard to Measure a Bank's Performance: A Case Study. International Journal of Business Administration, Vol. 3, No. 4, 44-51.

Ashton, C. (1998). Balanced Scorecard Benefits: NatWest Bank. International Journal of Retail \& Distribution Management, 26(10/11), 400-401.

Asosheh,A., Nalchigar,S., \& Jamporazmey,M. (2010). Information Technology Project Evaluation: An Integrated Data Envelopment Analysis and Balanced Scorecard Approach. Expert Systems with Applications, Vol.37, 5931-5938.

Bhagwat,R., \& Sharma,M.K. (2007). Performance Management of Supply Chain Management: A Balanced Scorecard Approach. Computers \& Industrial Engineering, Vol. 53, 43-62.

Chang, H. (2009). An Empirical Study of Evaluating Supply Chain Management Integration Using the Balanced Scorecard in Taiwan. The Service Industries Journal, 29 (2), 185-202.

Dave,S.R., \& Dave,S.R. (2012). Applying Balanced Scorecard in Indian Banking Sector: An Empirical Study of the State Bank of India. Pacific Business Review International, 5(6), 108-120.

Davis,S., \& Albright,T. (2004). An Investigation of the Effect of Balanced Scorecard Implementation on Financial Performance. Management Accounting Research, Vol .15, Issue 2, 135-153.

Eilat,H., Golany,B., \& Shtub,A. (2008). Research and Development Project Evaluation: An Integrated Data Envelopment Analysis and Balanced Scorecard Approach. Omega, Vol.36, 895-912.

Epstien,M.J., \& Wisner,P.S. (2001). Good Neighbors: Implementing Social and Environmental Strategies With the BSC. Harvard Business School Publishing Corporation. Balanced Scorecard Report. MayJune.

Eskandari,M., Roudabr,N., \& Kamfiroozi,M.H. (2013). Banks' Performance Evaluation Model Based on the Balanced Scorecard Approach, Fuzzy DEMATEL and Analytic Network Process. International Journal Of Information, Security and System Management, Vol. 2, No. 2, 191-200.

Fernandes,K.J., Raja,V., \& Whalley,A. (2006). Lessons from Implementing the Balanced Scorecard in a Small and Medium Size Manufacturing Organizations. Technovation, Vol. 26, Issues 5-6, 623-634.

Gupta,A.K., \& Sharma,S. (2016). Application of Balanced Scorecard in Banking Industry: A Review of Literature. International Journal of Economic and Business Review, Vol. 4, Issue 11, 135-144.

Ibrahim, M. (2015). Investigating the Use of the Four Perspectives of Balanced Scorecard (BSC) as Technique for Assessing Performance by Nigerian Banks. Journal of Accounting and Taxation, 7(4), 62-70.

Idalina,DS., Lucas,R., \& Paula,A. (2007). Developing Sustainability Balanced Scorecards for Environmental Services: A Study of Three Large Portuguese Companies. Environmental Quality Management, 16(4), 13-34.

Janota, R. (2008). The Balanced Scorecard in a Pharmaceutical Company. Instituto Superior de Ciencias do Trabalho e da Empresa: PhD Thesis.

Karasneh, A.A., \& Al-Dahir,A. (2012). Impact of IT-Balanced Scorecard on Financial Performance: An Empirical Study on Jourdanian Banks. European Journal of Economics, Finance and Administrative Sciences, Issue 46, 54-70.

Kirandeep, S. (2015). The Application of Balanced Scorecard as a Strategic Management Tool at National Bank of Kenya. School of Business, University of Nairobi.

Kuang - Hua, H. (2005). Using Balanced Scorecard and Fuzzy Data Envelopment Analysis for Multinational Research \& Development Project Performance Assessment. The Journal of American Acadeny of Business, Cambridge, 7(1), 189-196.

Kumar, S. (2015). Management Motivation for Implementing the Balanced Scorecard in Indian Banking Sector. International Journal of Trade and Commerce - IIARTC, 4(1), 147-159.

Kumar, S. (2016). Awareness Regarding Contemporary Performance Measures for Measuring Performance of Indian Banking Sector. International Journal of Engineering and Management Research (IJEMR), Vol. 6, Isuue 5, 1-7.

Lawson,R., Stratton,W., \& Hatch,T. (2006). Scorecarding Goes Glaobal. Stategic Finance, 87 (9), $34-41$. 
Luu,T-V., Kim, S-Y., Cao,H-L., \& Park, Y-M. (2008). Performance Measurement of Construction Firms in Developing Countries. Construction Management and Economics, 26 (4), 373-386.

Malmi, T. (2001). Balanced Scorecard in Finnish Companies: A Research Note. Management Accounting Research, Vol. 12, 207-220.

Ombuna,D.S., Omido,K., Garashi,H.M., Odera,O., \& Okaka,O. (2013). Impact of Balanced Scorecard Usage on the Performance of Commercial Banks. International Journal of Information Technology and Business Management, Vol. 10, No.1, 40-48.

Ozturk,E., \& Coskum,A. (2014). A Strategig Approach to Performance Management in Banks: The Balanced Scorecard. Accounting and Finance Research, Vol.3, No.3, 151-158.

Panicker,S., \& Seshadri,V. (2013). Devising a Balanced Scorecard to Determine Standard Chartered Bank's Performance: A Case Study. International Journal of Business Research and Development, Vol. 2, No $.2,35-42$.

Raphael,G., \& Man,W. (2013). Integrating Financial and Non Financial Measures to Measure the Performance of Commercial Banks: Evidence From Tanzania. Research Journal of Finance and Accounting, Vol. 4, No. 3, 1-11.

Rigby, D. (2001). Management Tools and Techniques: A Survey. California Management Review, 43(2), 139-160.

Rillyan, N.R., Satria,G., Raihan,A.M., \& Wibisono,D. (2016). A Study on Linkages Among Balanced Scorecard Persprctives: The Case of Indonesian Local Banks. First International Conference on Advanced Business and Social Sciences (ICABSS) (pp. 132-143). Bali: Asia Pacific Institute of Advanced Research (APIAR).

Rostami,M., Goudarzi,A., \& Zaj, M.M. (2015). Defining Balanced Scorecard Aspects in Banking Industry Using FAHP Approach. International Journal of Economics and Business Administration, Vol. 1, No. 1, 25-38.

Shaverdi,M., Akbari,M., \& Tafti,S. (2011). Combining Fuzzy MCDM with BSC Approach in Performance Evaluation of Iranian Banking Sector. Advances in Fuzzy Systems, Vol. 2011, Article No.1, ID 148712, $1-12$.

Silk, S. (1998). Automating the Balanced Scorecard. Management Accounting, 79(11), 38-44.

Tariq,M., Ahmad,S., \& Rafi,S.K. (2014). Investigating the Impact of Balanced Scorecard on Performance of Business: A Study Based on the Banking Sector of Pakistan. Journal of Business Studies (Formerly Journal of Management \& Social Sciences), Vol. 9, No.1, 125-136.

Tominac, S. (2014). Possibilities of Balanced Scorecard Application in Commercial Banks. International Journal of Scientific Research, Vol.3. Issue 10, 119-121.

Umar,G., \& Olatunde,O.J. (2011). Performance Evaluation of Consolidated Banks in Nigeria by Using Non-Financial Measures. Interdisciplinary Journal of Research in Business, 1(9), 72-83.

Visalakshi,S., \& Kasilingam,R. (2015). Balanced Scorecard Approach to Measure Performance of Banks. NBR E-Journal, Vol.1, issue 1, 1-8.

$\mathrm{Wu}$, H. (2012). Constructing a Strategy Map for Banking Institution with Key Performance Indicators of the Balanced Scorecard. Evaluation and Progress Planning, 35(3), 303-320.

Wu,H.Y., Lin,Y.K., \& Chang,C.H. (2011). Performance Evaluation of Extention Education Centers in Universities Based on the Blanced Scorecard. Evaluation and Programs Planning, Vol. 34, Issue 1, 37-50.

Wu,H-Y., Tzeng, G-H., \& Chen, Y-H. (2009). A Fuzzy MCDM Approach for Evaluating Banking Performance Based on Balanced Scorecard. Expert Systems with Applications, Vol. 36, Issue 6, 1013510147.

Yahya, A. (2009). Using Balanced Scorecard to Assess Performance of Banks in Ghana. Blekinge, Sweden: School of Management, Blekinge Institute of Technology.

Zhang,Y., \& Li, L. (2009). Study on Balanced Scorecard of Commercial Bank in Performance Management System. International Conference on Management and Service Science (pp. 206-209). Wuhan, China: IEEE Xplore Digital Library. 